\title{
Management and cultivar effects on ruminant nutritional quality of pearl millet (Pennisetum glaucum (L.) R. Br.) stover II. Effects of cultivar choice on stover quality and productivity
}

\author{
M. Blümmel ${ }^{\mathrm{a}, *}$, F.R. Bidinger ${ }^{\mathrm{b}}$, C.T. Hash ${ }^{\mathrm{b}}$

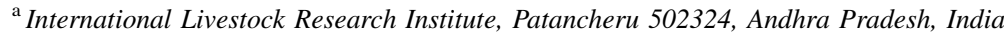 \\ ${ }^{\mathrm{b}}$ International Crops Research Institute for the Semi-Arid Tropics, Patancheru 502324, Andhra Pradesh, India
}

Received 20 December 2006; received in revised form 17 May 2007; accepted 17 May 2007

\begin{abstract}
The paper investigates the variation in laboratory fodder quality traits in stover of 16 cultivars of pearl millet grown over 2 consecutive years and subjected to two different fertilizer regimes and planting densities. Stover quality traits were nitrogen and sugar content, in vitro digestibility and metabolizable energy content as well as yield of digestible and metabolizable stover. Significant $(P<0.05)$ cultivar-dependent variations were observed for all these quality traits. Stover nitrogen contents were mostly below the levels ( $1.2 \%$ of dry matter) considered to be the minimum required for efficient feed digestion in the rumen, but choice of cultivar plus nitrogen fertilizer application could raise nitrogen levels to near, equal or above this threshold. Stover sugar contents were below $5 \%$ and mostly concentrated in the stems. Across management regimes stover in vitro digestibility varied by about $4 \%$ units, and by about 3-5\% units within individual management regimes. Stover metabolizable energy contents of cultivars varied such that stover from superior cultivars could provide the energy maintenance requirement of livestock and theoretically moderate levels of live weight gains, while livestock fed on stover from poor cultivars would lose live weight. Yields of digestible and metabolizable stover (yield of stover dry matter times stover in vitro digestibility/metabolizable energy) varied among cultivars by at least 1.7-fold. Stover quality traits and grain yields of cultivars were largely unrelated $(P>0.05)$ suggesting that high stover quality will not be achieved on the expense of grain yield. Heritabilities for stover quality traits were high $\left(h^{2}>0.73\right)$ except for stover nitrogen content $\left(h^{2}>0.56\right)$.
\end{abstract}

(C) 2007 Elsevier B.V. All rights reserved.

Keywords: Pearl millet; Stover productivity; Stover nutritional quality; Management effects; Cultivar effects

\section{Introduction}

One of the most effective and least-cost options open to farmers to increase both stover productivity and stover quality is the choice of cultivar, provided that there are significant differences among cultivars for both productivity and quality, and that emphasizing stover traits does not carry an unacceptable penalty in terms of reduction in grain yield. In addition, there may be potential synergies between higher input management and superior cultivars that can be exploited by farmers to maximize both stover production and quality. There are major benefits to farmers in both greater stover yields and improved stover quality, whether the stover is used for

\footnotetext{
* Corresponding author. Tel.: +91 4030713653.

E-mail address: m.blummel@cgiar.org (M. Blümmel).
}

maintaining draft or meat animals, for the production of milk for sale, or for direct sale in peri-urban markets, where there is a high demand by urban milk producers for good quality stover. For example, for sorghum stover, which is intensively traded in the peri-urban urban dairy environment in Hyderabad in India, cultivar-dependent variation in stover in vitro digestibility of 5 units $(46-51 \%)$ resulted in a $25 \%$ price difference ( 3 compared to 4 Indian Rupees) per kilogram dry sorghum stover (Blümmel and Rao, 2006).

A high demand for quality stover, and a consequently growing economic value (Kelley and Rao, 1996), has resulted in cereal breeding programs beginning to focus on the improvement of stover yield and quality as well as grain yield (Reddy et al., 1995; Hash et al., 2000). The ultimate success of crop breeding programs targeting increases in stover yield and improvement in stover quality depends on the existence of useful genetic variation in stover quantity and quality, and on 
the absence of competitive relationships between these and other desirable agronomic traits such as grain yield. Estimates based on ex ante impact assessments predict that improvement of stover quality through genetic enhancement can result in benefit:cost ratios of 15:1 and higher (Kristjianson and Zerbini, 1999), so the potential gains are real, if the conditions for simultaneous improvement in grain and stover are met.

The previous paper from this study (Bidinger and Blümmel, 2007) examined the effects of crop management variables on stover and grain productivity and stover quality in pearl millet. The objective of this part of the study was to assess (1) the range of variation among existing cultivars in both stover productivity and quality, (2) the relationship of these with each other and with grain yield, and the (3) effects of management variables on these relationships. In addition to quantifying the potential benefits of cultivar choice, the results of this study also have important implications for the future genetic improvement of stover quality of pearl millet.

\section{Materials and methods}

\subsection{Cultivars used}

The material used in the experiment represent diverse cultivar types adapted to the major arid and semi-arid pearl millet growing zones of NW India, primarily the state of Rajasthan and adjacent areas of the states of Haryana and Gujarat, in which pearl millet stover is widely used to feed domestic animals. They included (1) five representatives of traditional landraces, (2) six representatives of genetically improved dual-purpose (grain and stover) open-pollinated varieties with different amounts of traditional landrace germplasm content, and (3) five representatives of commercial $\mathrm{F}_{1}$ hybrids, bred primarily for grain yield (Table 2). The landrace materials are mainly unimproved populations, whose component landrace accessions had been selected by various plant breeders, but with little additional selection/improvement. They represent a range of the landrace types traditionally grown by farmers in the mixed cropping systems of Western and Central Rajasthan. The dual-purpose varieties, in contrast, are mainly products of a collaborative breeding program between the International Crops Research Institute for the Semi-Arid Tropics (ICRISAT), the Central Arid Zone Research Institute (CAZRI), Jodhpur, Rajasthan, and the Rajasthan Agricultural University designed to produce improved, dual-purpose cultivars for the arid and semi-arid zones (Yadav and Weltzien, 1998). Their parentage includes both landrace and nonlandrace materials; most have been selected for both grain and stover yield. The hybrids were bred primarily for grain yield, by public breeding programs at CCS Haryana Agricultural University (HHB 60), the Indian Agricultural Research Institute (IARI), New Delhi (Pusa 23 and BJ 104), and ICRISAT (ICMH hybrids). All have been released by the AllIndia Coordinated Pearl Millet Improvement Program for cultivation in the arid/semi-arid zones, and most have been widely grown by farmers in the past decade (Govila et al., 1997).

\subsection{Field experiments}

The 16 cultivars were grown in replicated field experiments in 2000 and 2001 under two levels of added fertility and two plant populations in a split-split plot design, with cultivar as the sub-sub plot. Fertility levels (main plot) were high (65 $\mathrm{kg} \mathrm{N} \mathrm{ha}^{-1}$ and $\left.18 \mathrm{~kg} \mathrm{Pha}^{-1}\right)$, and low $\left(21 \mathrm{~kg} \mathrm{~N} \mathrm{ha}^{-1}\right.$ and $9 \mathrm{~kg} \mathrm{P} \mathrm{ha}{ }^{-1}$ ), and plant populations (sub plot) were high $\left(11\right.$ plants $\left.\mathrm{m}^{-2}\right)$ and low $\left(5\right.$ plants $\left.\mathrm{m}^{-2}\right)$. These were designed to approximate research station (high) and farmer (low) input management levels. Details of the experimental design and field treatments are provided in Bidinger and Blümmel (2007).

Data were recorded on time to $50 \%$ flowering in all cultivars. At harvest, 30-35 days after the flowering of the last cultivar, panicles with seed were harvested from a bordered $3 \mathrm{~m}$ length of the center two rows of each plot, and data collected on panicle number per unit area, and on grain and panicle dry weights per unit area. Stover was cut at ground level and fresh weight was recorded, and sub samples taken for determining both moisture percentage and leaf and stem plus sheath ratios. Total stover production and leaf and stem fractions of the stover were calculated from the appropriate sub samples, on an oven dry basis. Total biomass per unit area was calculated from stover and panicle weights, and harvest index from the ratio of grain and biomass yields. Details of harvest and sample processing are provided in Bidinger and Blümmel (2007).

\subsection{Stover quality analysis}

In brief, stover nitrogen content, in vitro digestibility and in vitro metabolizable energy and sugar content were estimated using a combination of conventional chemical and in vitro laboratory analysis and near infrared spectroscopy. Stover productivity, percent digestibility and metabolizable energy data were used to estimate digestible dry matter and stover metabolizable energy yields per hectare. Details have been reported in Bidinger and Blümmel (2007).

\subsection{Statistical analysis}

The analysis of variance for the cultivar effect was done as part of the larger analysis of management treatment effects presented in Bidinger and Blümmel (2007) using SAS PROC GLM (SAS, 1988), which considered only the effects of cultivar type (traditional landrace, open-pollinated variety, and $F_{1}$ hybrid). The full analysis included the effects of cultivar (13 df) nested within cultivar type (as indicated in Table 2), and the interactions of cultivar with year and with all management factors. Linear relationships between grain and stover traits for individual management variables were calculated and presented in figures using GraphPad Prism (1994). For relationships with probability values of $<0.1$, correlation coefficients were reported in the figures while for probability values $>0.1$ only $P$ values were reported. 


\section{Results and discussion}

\subsection{Cultivar differences in stover productivity and quality}

There were highly significant differences among cultivars for all productivity and quality variables measured in the experiment (Table 1). However, the presence of significant interactions of cultivar and year for total stover yield, and for most stover quality parameters, indicate that cultivar differences are not independent of environmental differences among years. Similarly, there were significant cultivar $\times$ fertility interactions for biomass, grain and all measures of stover yield; cultivar $\times$ fertility interactions, however, were generally not significant for stover quality parameters (Table 1). Cultivar $\times$ plant population interactions were generally not important for either productivity or quality variables. The lack of significant fertility $\times$ cultivar and plant population $\times$ cultivar effects for stover quality is encouraging, as cultivar differences in stover quality should be consistent across different management intensities, and thus exploitable by farmers with different levels of intensity of management, even if cultivar differences in quality may not always be consistent across all the years. Despite the presence of various cultivar $\times$ environments interactions, however, broad-sense heritabilities for most key target traits were greater than 0.73 with the exception of stover leaf percentage $\left(h^{2}=0.35\right)$ and stover nitrogen content $\left(h^{2}=0.56\right)$, indicating that cultivar differences were still considerably larger than the cultivar $\times$ environment interactions measured in this study.

There were very large differences (1.5-2.0-fold ranges) in the cultivar means (averaged across years and management treatments) for basic yield variables. Cultivar mean biomass ranged from $399 \mathrm{~g} \mathrm{~m}^{-2}$ to $712 \mathrm{~g} \mathrm{~m}^{-2}$, grain yields from $118 \mathrm{~g} \mathrm{~m}^{-2}$ to $267 \mathrm{~g} \mathrm{~m}^{-2}$, and stover yield from $223 \mathrm{~g} \mathrm{~m}^{-2}$ to $376 \mathrm{~g} \mathrm{~m}^{-2}$ (Table 2). In general, biomass yields were slightly higher in the dual-purpose and hybrid cultivars than in the landraces, but there was considerable overlap in this. There was no clear pattern in stover yields, but grain yields generally followed the order of hybrids $>$ dual-purpose $>$ landraces, following similar and pronounced differences in harvest index among the three types of cultivars. This is an obvious reflection of the importance given to selection for grain yield in the breeding of the dual-purpose and hybrid cultivars.

Similarly, cultivars differed significantly in all stover quality parameters (Table 3). Absolute ranges in stover quality parameters across treatments were generally smaller than those in productivity variables, but of a generally similar magnitude in terms of the multiple of the least significant difference among cultivars. Stover nitrogen content ranged from 0.74 to $0.93 \%$, thus falling short of the $1-1.2 \%$ of nitrogen that is considered to be the minimum amount to assure efficient microbial degradation of feed in the rumen of livestock (Van Soest, 1994). Nitrogen contents below the minimum microbial requirement result in reduced feed intake and perhaps digestibility. Van Soest (1994) reported data that show feed intake could double when feed nitrogen content increased from 0.4 to $1.2 \%$. It can be estimated from this data set ( $\mathrm{N}$ range 0.4 $1.2 \%$ ) that a $0.1 \%$ increase in feed nitrogen resulted in increased intake of more than 10\% (Van Soest, 1994). Extrapolation of these estimates to the current data would suggest about 25\% differences in feed intake between cultivars because of across treatment differences in stover nitrogen content (0.74-0.93\%; Table 3). These extrapolations are supported by very recent work with 34 pearl millet stover where regression analysis predicts that a rise in stover nitrogen content from 0.49 to $1.11 \%$ is associated with an increase in $\mathrm{ad}$ libitum intake of stover by sheep from 19.2 to $25 \mathrm{~g} / \mathrm{day} / \mathrm{kg} \mathrm{LW}$ (Alexander et al. unpublished).

The range in stover in vitro digestibility was $3.8 \%$ (38.9$42.7 \%$, Table 3), which seems small but is of significance nonetheless, as will be discussed in more detail further on. Metabolizable energy (ME) content is an estimate of feed quality that is closer to the net energy (NE) actually available to the animal than is digestible energy, since the ME measurement takes account of energy losses in urine and methane (McDonald et al., 1988). Net energy can be calculated from ME by the use

Table 1

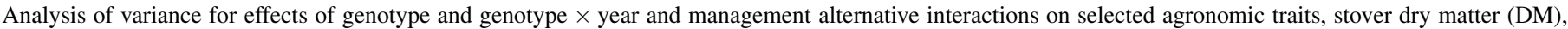
digestible dry matter (DDM) and metabolizable energy (ME) yields and stover quality traits

\begin{tabular}{|c|c|c|c|c|c|}
\hline Variable & Genotype (cultivar type) & Genotype $\times$ year & Genotype $\times$ fertility & Genotype $\times$ plant population & Heritability \\
\hline Panicles plant $^{-1}$ & $* * * *$ & ****** & NS & ****** & 0.65 \\
\hline Biomass & $* * * *$ & NS & $* * *$ & NS & 0.86 \\
\hline Grain yield & $* * * *$ & NS & $* * * * *$ & $*$ & 0.88 \\
\hline Harvest index & $* * * *$ & $* * * *$ & $* *$ & $* *$ & 0.93 \\
\hline Stover DM yield & $* * * *$ & $* *$ & $* *$ & NS & 0.88 \\
\hline Stover DDM yield & $* * * *$ & $* *$ & $* * *$ & NS & 0.85 \\
\hline Stover ME yield & $* * * *$ & $* *$ & NS & NS & 0.73 \\
\hline Stover leaf $(\%)$ & $* * * *$ & $* * * *$ & NS & NS & 0.35 \\
\hline Stover N (\%) & $* * * *$ & $* * * *$ & NS & NS & 0.56 \\
\hline Stover digestibility (\%) & ***** & * & NS & NS & 0.94 \\
\hline Soluble sugars $(\%)$ & $* * * *$ & * & NS & NS & 0.83 \\
\hline Metabolizable energy & $* * * *$ & NS & NS & NS & 0.85 \\
\hline
\end{tabular}

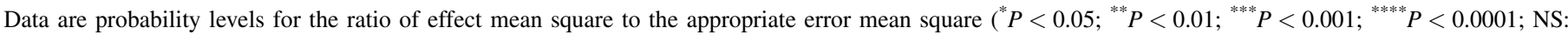
$P>0.05)$. 
Table 2


digestible dry matter (DDM) and metabolizable energy (ME) yields

\begin{tabular}{|c|c|c|c|c|c|c|c|}
\hline \multirow[t]{2}{*}{ Genotype } & \multirow{2}{*}{$\begin{array}{l}\text { Panicles } \\
\text { plant }^{-1}\end{array}$} & \multirow{2}{*}{$\begin{array}{l}\text { Biomass } \\
\text { yield }\left(\mathrm{g} \mathrm{m}^{-2}\right)\end{array}$} & \multirow{2}{*}{$\begin{array}{l}\text { Grain } \\
\text { yield }\left(\mathrm{g} \mathrm{m}^{-2}\right)\end{array}$} & \multirow{2}{*}{$\begin{array}{l}\text { Harvest } \\
\text { index }(\%)\end{array}$} & \multicolumn{3}{|c|}{ Stover yield $\left(\mathrm{m}^{-2}\right)$} \\
\hline & & & & & DM yield (g) & DDM yield (g) & ME yield (MJ) \\
\hline \multicolumn{8}{|l|}{ Landraces } \\
\hline Barmer Popln & 3.02 & 552 & 146 & 26.2 & 338 & 138 & 1.88 \\
\hline Jakharana Popln & 1.66 & 551 & 176 & 31.3 & 313 & 127 & 1.58 \\
\hline ICMP 94582 & 2.36 & 482 & 129 & 27.0 & 299 & 122 & 1.39 \\
\hline Raj 1 & 2.32 & 570 & 166 & 28.0 & 342 & 142 & 1.93 \\
\hline Pak LR Popln & 3.94 & 399 & 118 & 30.2 & 224 & 088 & 1.16 \\
\hline \multicolumn{8}{|l|}{ Dual-purpose } \\
\hline Raj 171 & 2.04 & 666 & 234 & 34.4 & 350 & 145 & 1.96 \\
\hline ICMV 97871 & 3.20 & 583 & 183 & 31.3 & 325 & 133 & 1.80 \\
\hline CZ-IC 923 & 1.84 & 600 & 221 & 36.4 & 309 & 121 & 1.54 \\
\hline RCB-IC 911 & 1.69 & 610 & 246 & 39.5 & 298 & 124 & 1.56 \\
\hline RCB 2 (99) & 2.60 & 607 & 203 & 32.8 & 322 & 126 & 1.65 \\
\hline DP Popln & 2.92 & 516 & 170 & 32.5 & 278 & 110 & 1.47 \\
\hline \multicolumn{8}{|l|}{ Hybrids } \\
\hline Pusa 23 & 2.51 & 593 & 240 & 39.7 & 276 & 106 & 1.34 \\
\hline ICMH 356 & 2.66 & 593 & 267 & 43.7 & 255 & 100 & 1.23 \\
\hline ICMH 451 & 2.11 & 696 & 256 & 35.0 & 376 & 155 & 1.80 \\
\hline ННВ 60 & 3.38 & 712 & 261 & 35.9 & 368 & 147 & 1.89 \\
\hline BJ 104 & 3.40 & 516 & 210 & 39.4 & 223 & 085 & 1.09 \\
\hline Trial mean & 2.60 & 575 & 201 & 34.0 & 304 & 122 & 1.80 \\
\hline S.E. & 0.079 & 14.4 & 5.8 & 0.48 & 9.6 & 4.0 & 0.725 \\
\hline Range & 2.28 & 313 & 149 & 17.5 & 153 & 70 & 0.87 \\
\hline L.S.D. (5\%) & 0.29 & 52.4 & 21.0 & 1.77 & 35.0 & 16.6 & 0.201 \\
\hline
\end{tabular}

Table 3

Genotype means, trial means and standard errors and least significant differences among entry means $(P<0.05)$ for pearl millet stover quality variables

\begin{tabular}{|c|c|c|c|c|c|}
\hline \multirow[t]{2}{*}{ Genotype } & \multicolumn{5}{|c|}{ Stover quality variables } \\
\hline & Leaf $(\%)$ & Nitrogen $(\%)$ & Digestibility (\%) & Soluble sugars $(\%)$ & $\overline{\mathrm{ME}\left(\mathrm{MJ} \mathrm{kg}^{-1}\right)}$ \\
\hline \multicolumn{6}{|l|}{ Landraces } \\
\hline Barmer Popln & 30.3 & 0.767 & 41.7 & 3.68 & 5.74 \\
\hline Jakharana Popln & 32.9 & 0.801 & 41.6 & 3.93 & 5.64 \\
\hline ICMP 94582 & 33.1 & 0.839 & 41.7 & 3.67 & 5.64 \\
\hline Raj I & 29.7 & 0.797 & 42.2 & 4.29 & 5.87 \\
\hline Pak LR Popln & 28.6 & 0.913 & 40.0 & 2.74 & 5.40 \\
\hline \multicolumn{6}{|l|}{ Dual-purpose } \\
\hline Raj 171 & 33.7 & 0.768 & 42.3 & 3.96 & 5.79 \\
\hline ICMV 97871 & 32.4 & 0.829 & 41.6 & 3.62 & 5.69 \\
\hline CZ-IC 923 & 33.3 & 0.809 & 40.3 & 3.12 & 5.35 \\
\hline RCB-IC 911 & 34.5 & 0.802 & 42.5 & 3.73 & 5.75 \\
\hline RCB 2 (99) & 33.2 & 0.839 & 40.6 & 3.17 & 5.41 \\
\hline DP Popln & 28.9 & 0.886 & 40.1 & 2.99 & 5.48 \\
\hline \multicolumn{6}{|l|}{ Hybrids } \\
\hline Pusa 23 & 34.5 & 0.839 & 39.6 & 2.73 & 5.17 \\
\hline ICMH 356 & 31.6 & 0.887 & 40.1 & 2.87 & 5.36 \\
\hline ICMH 451 & 34.6 & 0.744 & 42.7 & 3.71 & 5.67 \\
\hline ННВ 60 & 32.9 & 0.812 & 41.3 & 2.94 & 5.47 \\
\hline BJ 104 & 29.9 & 0.931 & 38.9 & 2.40 & 5.12 \\
\hline Trial mean & 32.2 & 0.829 & 41.1 & 3.34 & 5.53 \\
\hline S.E. (mean) & 0.93 & 0.0204 & 0.22 & 0.119 & 0.056 \\
\hline Range & 6.0 & 0.187 & 3.8 & 1.89 & 0.75 \\
\hline L.S.D. $(5 \%)$ & 3.38 & 0.0744 & 0.82 & 0.331 & 0.155 \\
\hline
\end{tabular}


Table 4

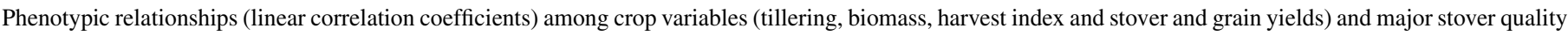
variables, and stover DM, DDM and ME yields

\begin{tabular}{|c|c|c|c|c|c|}
\hline \multirow[t]{2}{*}{ Stover quality/productivity traits } & \multicolumn{5}{|c|}{ Crop productivity variables } \\
\hline & Tillering & Biomass & Harvest index & Grain yield & Stover yield \\
\hline Leaf $(\%)$ & $-0.65^{* *}$ & $0.68^{* *}$ & 0.33 & $0.61^{*}$ & 0.48 \\
\hline $\mathrm{N}(\%)$ & $0.61^{* *}$ & $-0.65^{* *}$ & 0.28 & -0.22 & $-0.90^{* * *}$ \\
\hline Digestibility (\%) & $-0.51^{*}$ & 0.44 & -0.39 & 0.03 & $0.79^{* * *}$ \\
\hline Soluble sugars $(\%)$ & $-0.60^{* *}$ & 0.24 & $-0.53^{*}$ & -0.18 & $0.67^{* *}$ \\
\hline Metabolizable energy & -0.39 & 0.21 & $-0.57^{*}$ & -0.21 & $0.65^{* * *}$ \\
\hline Stover DM yield & -0.39 & $0.75^{* * *}$ & 0.32 & 0.25 & - \\
\hline Stover DDM yield & -0.42 & $0.71^{* *}$ & -0.35 & 0.20 & $0.99^{* * * *}$ \\
\hline Stover ME yield & -0.29 & $0.64^{* *}$ & -0.41 & 0.11 & $0.94^{* *}$ \\
\hline
\end{tabular}

The data are genotype $(N=16)$ means across years, fertility levels and plant populations.

${ }^{*} P<0.05$.

** $P<0.01$

**** $P<0.001)$.

of an efficiency factor $k(k>0<1)$, which in turn depends on the ME content of a feed. Thus for the genotypes with the highest $(5.87 \mathrm{MJ} / \mathrm{kg})$ and lowest $(5.12 \mathrm{MJ} / \mathrm{kg})$ stover $\mathrm{ME}$ content in Table 3 , the $k$ for maintenance energy would be 0.62 and 0.60 and the NE they provide would be 3.63 and $3.07 \mathrm{MJ} /$ $\mathrm{kg}$, respectively (calculated according to McDonald et al., 1988). Livestock with a bodyweight of $250 \mathrm{~kg}$ - that is one tropical livestock unit - will have a NE requirement of $21.4 \mathrm{MJ} /$ day for maintenance requirement, meaning that an animal would need to consume 5.9 and $6.97 \mathrm{~kg}$ from the stover with high and low ME, respectively, to provide for this requirement. The highest pearl millet stover intake observed in our work was $2.6 \%$ of an animals live weight (Vellaikumar et al., 2006), which would amount to $6.5 \mathrm{~kg} /$ day in the case of a $250 \mathrm{~kg}$ animal. At these high intake level an animal offered the pearl millet stover having high ME could maintain energy equilibrium (and theoretically even gain some energy), while the animal fed the stover of low ME would lose body weight.
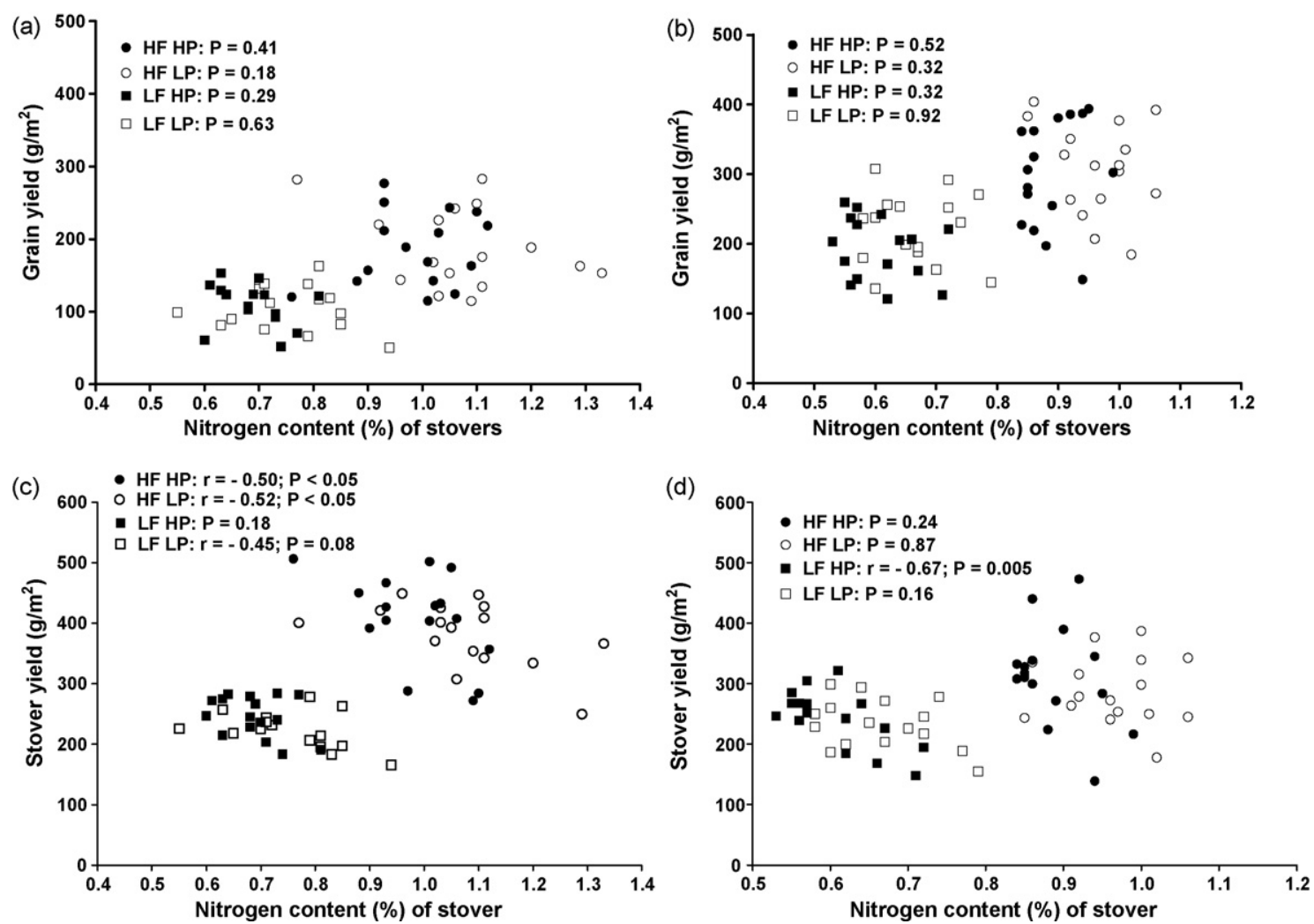

Fig. 1. (a) Relations between nitrogen content of stover and grain yield under two levels of fertility and population density in year 2000. (b) Relations between nitrogen content of stover and grain yield under two levels of fertility and population density in year 2001. (c) Relations between nitrogen content of stover and stover yield under two levels of fertility and population density in year 2000. (d) Relations between nitrogen content of stover and stover yield under two levels of fertility and population density in year 2001 . 


\subsection{Relationships of grain and stover yields and stover quality}

Phenotypic relationships between stover quality and stover and grain yields, are of particular concern, as these indicate the potential trade-offs involved in growing cultivars selected for a higher stover quality. These are reported on the basis of across year and management treatment in Table 4. Key relationships between the important stover quality estimates and both stover and grain yields were examined in individual years, and fertility and plant density management levels to evaluate effects of year and management treatment on overall relationships in Figs. 1-5.

\subsubsection{Relationships between stover $N$ and grain and stover yield}

Low nitrogen content is often considered to be one of the most limiting factors in the utilization of cereal straws as livestock fodder, as N\% below 1.0-1.2\% of stover dry matter depresses voluntary feed intake through the effect of lack of $\mathrm{N}$ on rumen microbes (Van Soest, 1994). Voluntary feed intake in turn is the most important quality trait in cereal crop residues wherever farmers have enough crop residue quantity to feed their animals according to appetite (Blümmel et al., 2003). Increasing nitrogen content through plant breeding and selection could overcome this constraint. In the present work, stover nitrogen contents and grain yields were unrelated $(P>0.05)$, however, some significant inverse relationships were observed between stover $\mathrm{N}$ and stover yields, depending on treatment and year (Fig. 1a-d). Overall, the correlation between stover N\% and stover yield was strongly negative $(r=-.90, P<0.001$; Table 4$)$.

There was a strong cultivar effect $(P<0.0001$; Table 1$)$ on stover nitrogen content but the heritability of stover nitrogen was not very high $\left(h^{2}=0.56\right.$; Table 1$)$. From this perspective the scope for breeding and selection of pearl millet stover for high nitrogen content appears therefore limited, even thought it would probably be possible without reduction in grain yield (Fig. 1a and b). On the other hand fertilizer application had a strong positive effect on stover nitrogen content, increasing nitrogen content in some cultivars to a level that would suffice to meet the minimum microbial nitrogen requirement of 1 to $1.2 \%$ (Van Soest, 1994). Increasing stover nitrogen content through fertilizer application is clearly preferable to genetic interventions (where this is economically feasible), since total biomass and stover productivity is also significantly increased.

\subsubsection{Relationships between stover sugar content and grain and stover yield}

In participatory rural appraisals conducted in India, stover sweet taste was an important sensual perception of stover quality for farmers when they ranked pearl millet stover for fodder quality (Underwood et al., 2000). In the present work, sugar content was used as a laboratory approximation for sweet taste. As Fig. 2a and b shows, stover sugar content was largely
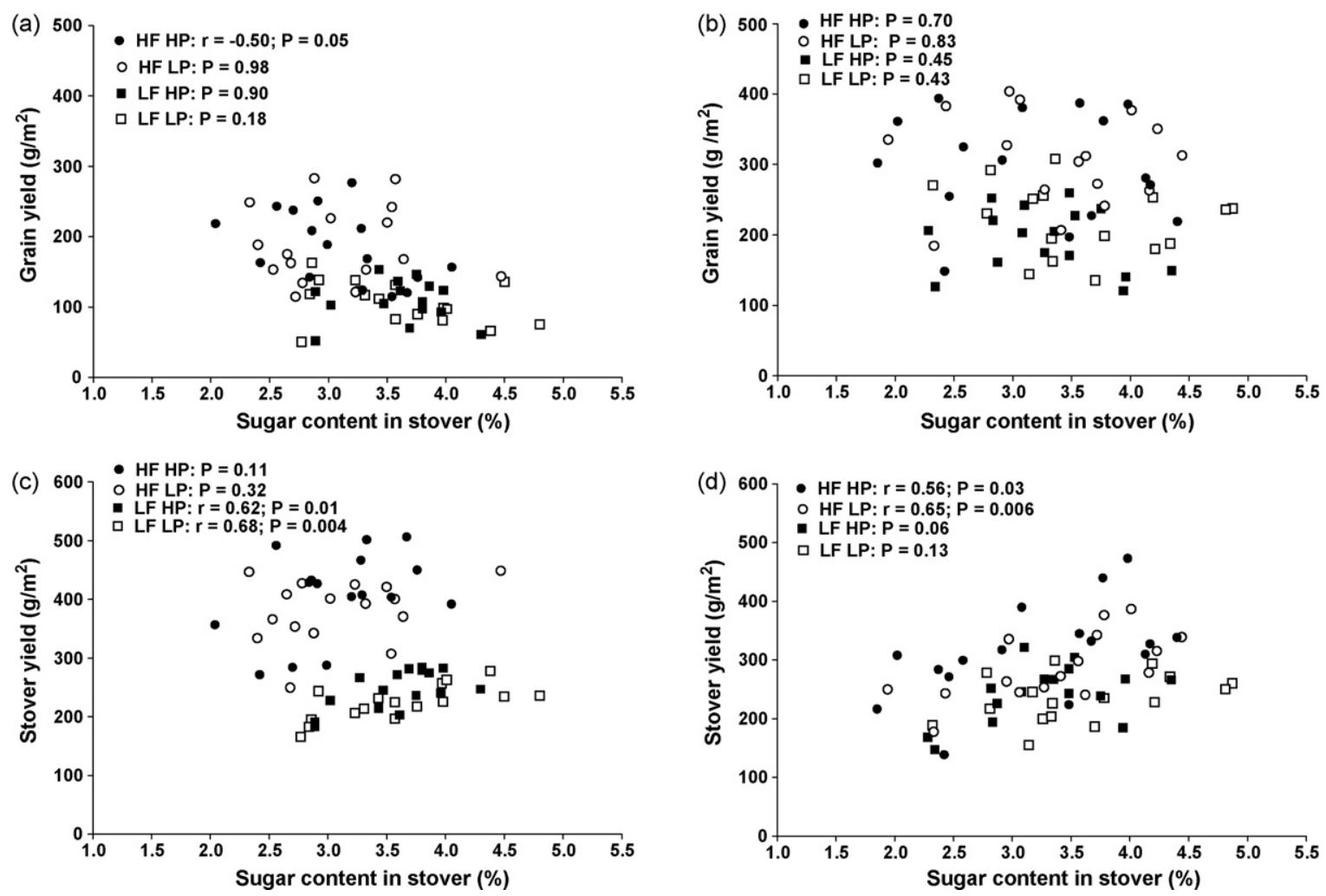

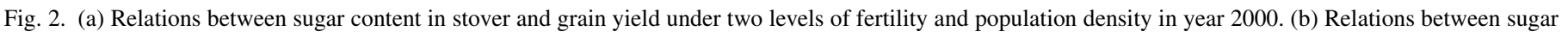

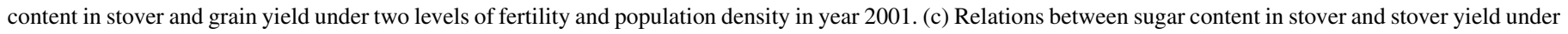

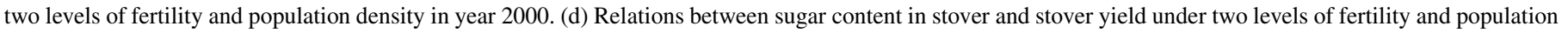
density in year 2001 . 

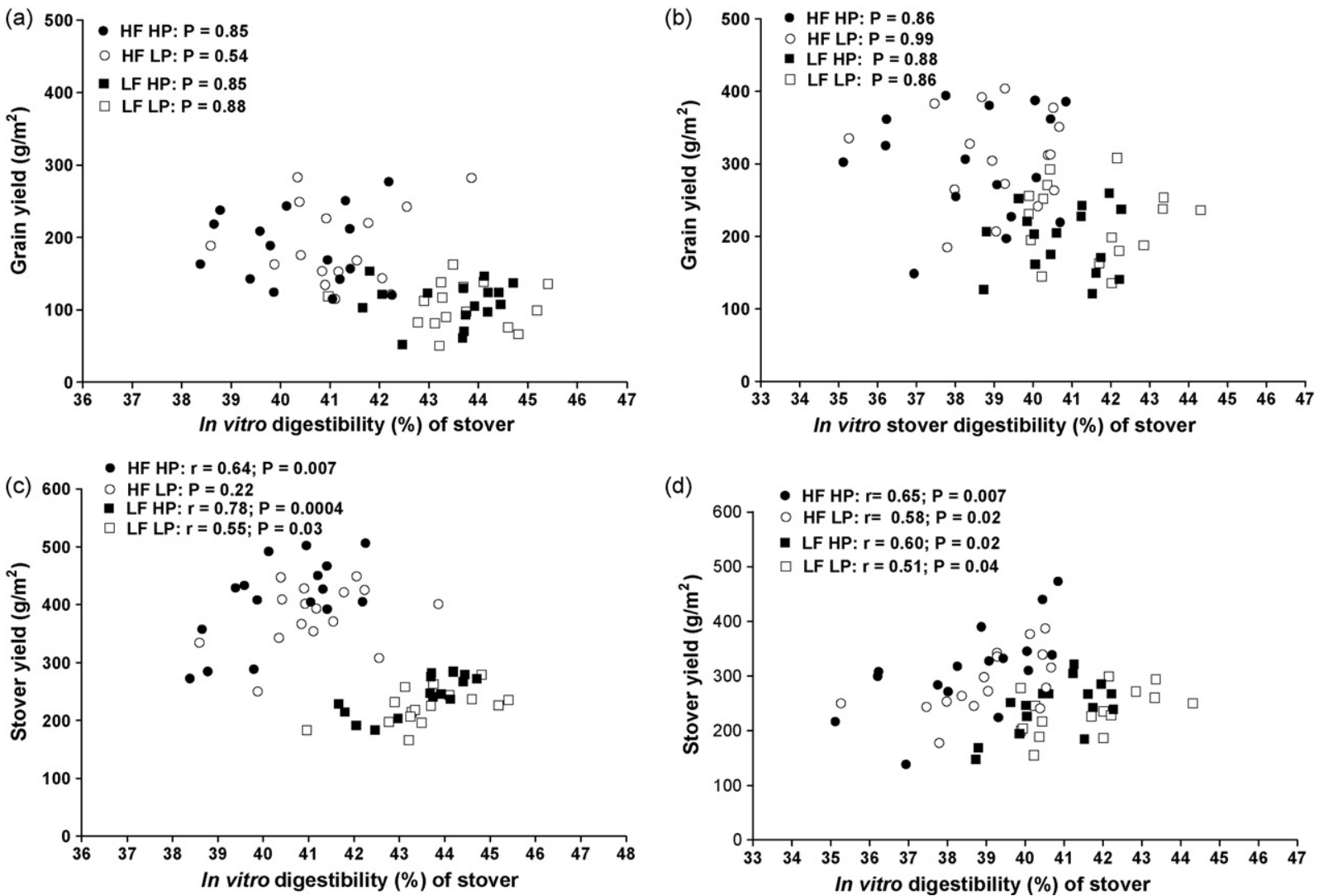

Fig. 3. (a) Relations between in vitro digestibility of stover and grain yield under two levels of fertility and population density in year 2000. (b) Relations between in vitro digestibility of stover and grain yield under two levels of fertility and population density in year 2001. (c) Relations between in vitro digestibility of stover and stover yield under two levels of fertility and population density in year 2000. (d) Relations between in vitro digestibility of stover and stover yield under two levels of fertility and population density in year 2001.

unrelated to grain yield except in the HF + HP treatment in 2000 where a just significant inverse relationship $(P=0.05)$ was observed. The relationships between stover sugar content and stover yields were generally positive and significant or approaching significance (Fig. $2 \mathrm{~b}$ and c). The overall cultivar effect on stover sugar content was strong $(P<0.0001)$ with a high heritability, suggesting that breeding and selection for higher sugar content is feasible and effective (Table 1).

However, sugar content in pearl millet stover and actual livestock productivity measurements were not always well related either in cattle (Blümmel et al., 2003) or in sheep (Prasad et al., 2006). Sugar content in pearl millet stover is concentrated in the stems, and high stover sugar content in whole stover could reflect a high stem proportion in whole stover with moderate sugar concentration in the stem itself. A high stem proportion in turn depresses voluntary feed intake, since in most crop residues stems are much harder than leaves for the animal to chew (Blümmel et al., 1996). Breeding for higher stover sugar content in whole stover should therefore monitor stem:leaf proportions to prevent inadvertent selection for high stem proportions in whole stover.

\subsubsection{Relationships between stover in vitro digestibility and grain and stover yield}

Across treatments, stover in vitro digestibility ranged from 38.9 to $42.7 \%$ i.e. the exploitable cultivar variation was $3.8 \%$ units. Within individual treatments this range was slightly higher-about 3-5\% units (Fig. 3a-d). Digestibility was the key variable in ex ante impact assessments of the genetic enhancement of sorghum and pearl miller stover as livestock fodder (Kristjianson and Zerbini, 1999). These authors calculated that a one-percentage unit increase in digestibility would result in increases in milk, meat and draught power outputs ranging from 6 to $8 \%$. In sorghum stover a cultivardependent difference of 5 percentage units (46-51\%) in in vitro digestibility equated to a $25 \%$ higher price (4 Indian Rupees per $\mathrm{kg}$ of dry stover compared to 3 Rupees) in a year-long survey of stover traders in Hyderabad (Blümmel and Rao, 2006). For grasses, a $3-4 \%$ difference in digestibility was associated with $17-24 \%$ differences in animal performance (Vogel and Sleper, 1994). Thus even though the observed ranges in stover in vitro digestibility of 3-5\% units appear small, they are nevertheless of considerable economic relevance.

Differences in stover in vitro digestibility can be exploited without detriment to grain yield since for a given fertilizer level, population density and year of planting, stover in vitro digestibilities and grain yields were unrelated (Fig. 3a and b). This was reflected in an overall correlation of stover digestibility and grain yield of $0.04(P>0.89$; Table 4$)$. Stover in vitro digestibility and stover yield were significantly positively associated in 7 out of 8 year $\times$ management 

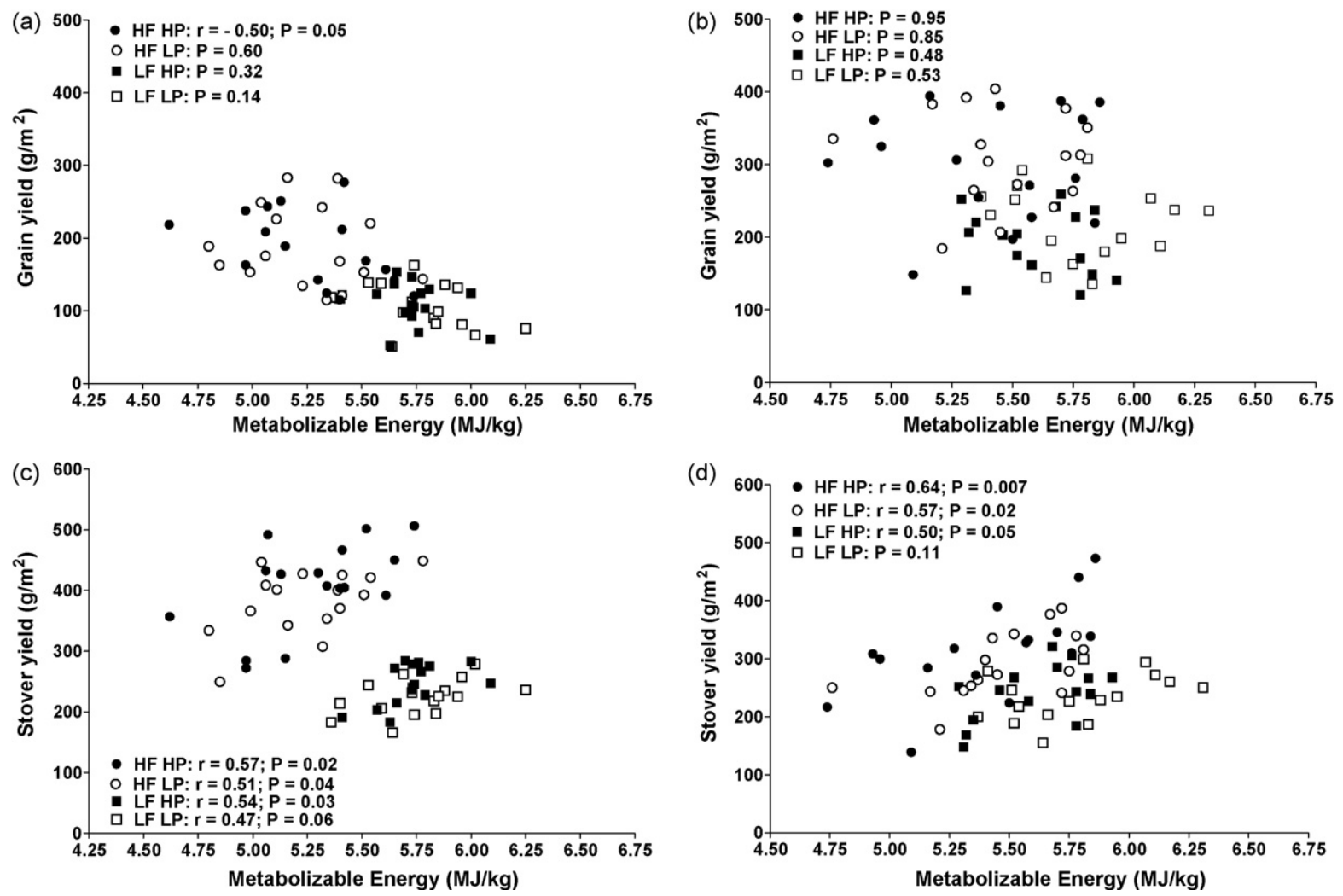

Fig. 4. (a) Relations between metabolizable energy content of stover and grain yield under two levels of fertility and population density in year 2000. (b) Relations between metabolizable energy content of stover and grain yield under two levels of fertility and population density in year 2001. (c) Relations between metabolizable energy content of stover and stover yield under two levels of fertility and population density in year 2000. (d) Relations between metabolizable energy content of stover and stover yield under two levels of fertility and population density in year 2001.

combinations, with stronger associations observed for the HP compared to the LP treatments in both years (Fig. 3c and d). The overall correlation between stover yield and stover digestibility was $0.79(P<0.001$; Table 4$)$. Apart from this relationship stover digestibility was not strongly associated with any particular phenotype (Table 4).

\subsubsection{Relationships between stover metabolizable energy content and grain and stover yield}

Except for the HF + HP treatment, where ME content of stover and grain yield were weakly but significantly inversely related $(P=0.05)$, no significant relationships were observed between these two variables (Fig. 4a and b). Stover ME content and stover yield were largely positively associated, in most cases significantly (Fig. $4 \mathrm{c}$ and d). As outlined previously, high and low values of ME stover content of 5.87 and $5.12 \mathrm{MJ} / \mathrm{kg}$ would result in the animal maintaining or losing body condition, respectively. It is encouraging to note that cultivars with highest grain yields (approximately $400 \mathrm{~g} / \mathrm{m}^{2}$ ) measured in all treatments had ME contents in their stover that could provide maintenance requirements (Fig. 4b). In fact, such stover ME levels were to be found in most treatments since in 2000 ranges in ME contents were: $\mathrm{HF}+\mathrm{HP}=4.62-5.74 \mathrm{MJ} / \mathrm{kg} ; \mathrm{HF}+\mathrm{LP}=4.80-5.78 \mathrm{MJ} /$ $\mathrm{kg} ; \mathrm{LF}+\mathrm{HP}=5.41-6.09 \mathrm{MJ} / \mathrm{kg}$ and $\mathrm{LF}+\mathrm{LP}=5.36-6.28 \mathrm{MJ} /$ kg. In 2001 ranges in $\mathrm{ME}$ content were: $\mathrm{HF}+\mathrm{HP}=4.74$
$5.86 \mathrm{MJ} / \mathrm{kg} ; \quad \mathrm{HP}+\mathrm{LF}=4.76-5.81 \mathrm{MJ} / \mathrm{kg} ; \quad \mathrm{LF}+\mathrm{HP}=5.29$ $5.93 \mathrm{MJ} / \mathrm{kg}$ and $\mathrm{LF}+\mathrm{LP}=5.37-6.31 \mathrm{MJ} / \mathrm{kg}$.

\subsubsection{Relationships between digestible stover yield, stover metabolizable energy yield and grain yield}

The smallholder farmers with mixed crop-livestock farming need stover quantity and quality, but the relative importance of the two traits is not always clear, and may vary between the farmers. Stover quantity and quality can be expressed in a combined way, for example as digestible stover yield (stover yield times stover digestibility) or yield of stover metabolizable energy (stover yield times metabolizable energy content of stover). This combined expression is unproblematic when no inverse relationships exist between quantity and quality, as was the case in the present work (Figs. 3 and $4 \mathrm{c}$ and d).

Stover quantity times quality measurements were largely independent of grain yields (Fig. 5a-d). Digestible stover dry matter yield and grain yield were mostly unrelated except for the HP + HF treatment in 2001 where digestible stover yield and grain yield were significantly positively associated. Across all treatments this correlation was not significant $(r=0.19$, $P=0.45$; Table 4). Similarly stover metabolizable energy yields and grain yields were unrelated except for the HP $+\mathrm{HF}$ treatment in 2001 (Fig. 5c and d). Cultivar-dependent ranges in digestible stover and metabolizable energy yields were 

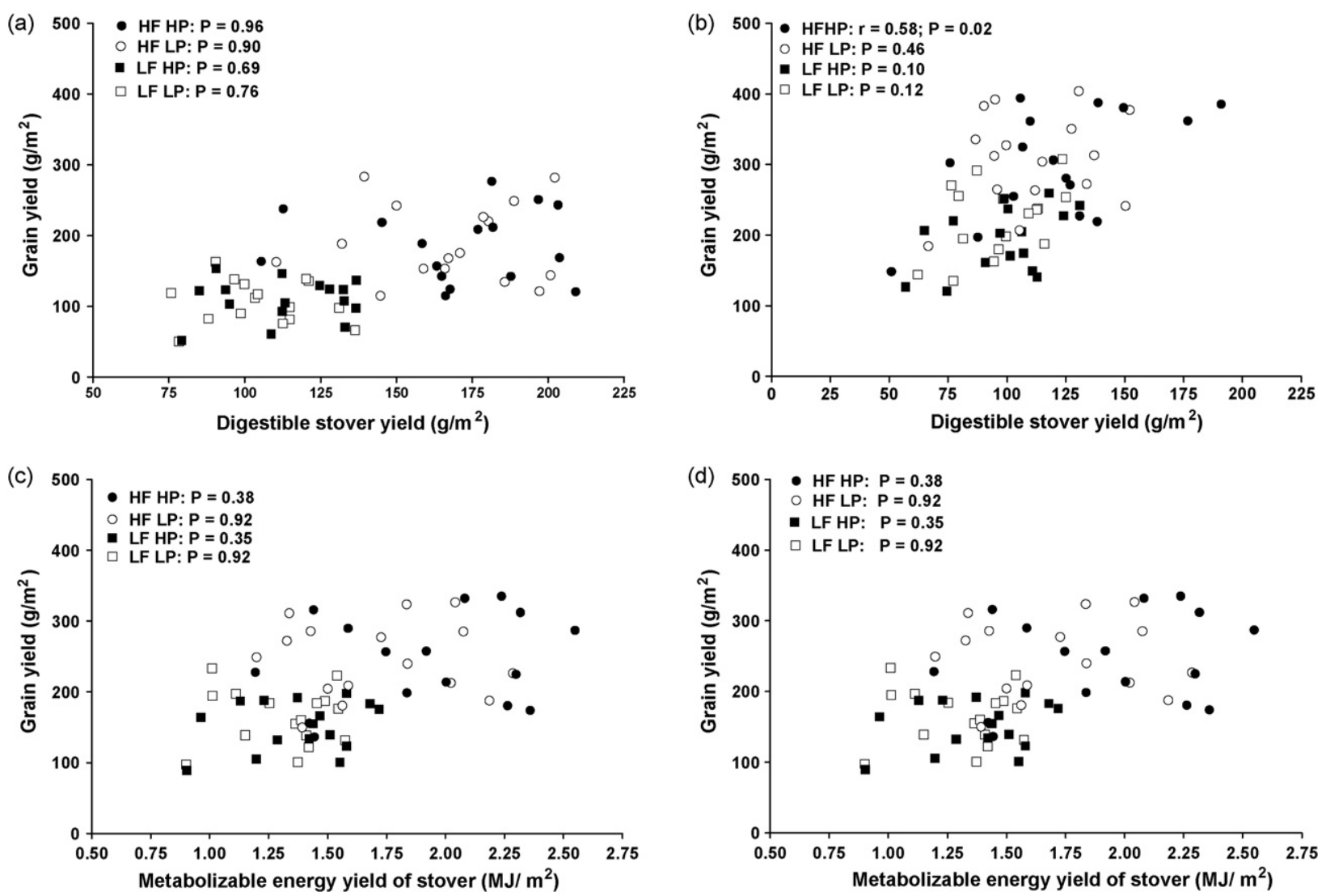

Fig. 5. (a) Relations between digestible stover yield and grain yield under two levels of fertility and population density in year 2000. (b) Relations between digestible stover yield and grain yield under two levels of fertility and population density in year 2001. (c) Relations between metabolizable energy yield of stover per $\mathrm{m}^{2}$ and grain yield under two levels of fertility and population density in year 2000. (d) Relations between metabolizable energy yield of stover per $\mathrm{m}^{2}$ and grain yield under two levels of fertility and population density in year 2001.

substantial, attaining at least 1.7-fold difference within a treatment (Fig. 5a-d).

\subsection{Cultivar choice and breeding for stover yield/quality}

Generally there were few strong patterns among the three cultivar types in quality parameters; cultivars with higher values for all quality variables were spread across all groups. For example, cultivars with the highest mean $\%$ digestibility (>42\%) included Raj 1 (landrace), Raj 171 and RCB-IC 911 (dual-purpose) and ICMH 451 (hybrid). Cultivars with the three highest yields of metabolizable stover included, in descending order, Raj 171 (dual-purpose), Raj 1 (landrace) and HHB 60 (hybrid).

The most interesting cultivars were the two hybrids ICMV 451 and HHB 60, which as well as producing the highest total stover and stover DDM, also produced the second and third highest grain yields in the trial (Table 2). Both are clearly more dual-purpose than pure grain-type hybrids, and demonstrate the potential for exploiting heterosis in pearl millet to increase total biomass to produce both high grain and high stover yields. Although the hybrids as a cultivar type had lower digestibility (Table 3), individual hybrids such as those cited above were in no way inferior to the better dual-purpose cultivars. The heritabilities of digestible stover yield and metabolizable energy yields yield were high (0.85) suggesting that these parameters are largely determined by genetic differences, and therefore exploitable in the breeding of dual-purpose hybrids.

\section{Summary}

Dual-purpose cultivars can be developed by essentially two approaches, namely by exploiting variation in already existing genotypes and by targeted further genetic enhancement. The first approach is quick and does not need much investment, since only screening of genotypes for stover quantity and quality is required. The second is a long-term approach and does require some investment; but there is an excellent potential to improve dual-purpose traits above their current level. However, certain conditions need to be met for both approaches. First, nutritionally significant variation is required in stover quantity and quality. Second, improvements in stover quantity and quality should not be achieved at the expense of grain yield (or other primary traits). Finally, stover quantity and quality need to have strong genetic components i.e. high heritabilities. The work presented here has demonstrated that all these conditions are met for pearl millet. It is interesting to note that the conventional definitions of "dual-purpose" and "grain" type pearl millets might actually miss the point, since some of the cultivars with the highest grain yields have also 
excellent stover traits. These relations of course could only become evident after crop improvement and livestock jointly started investigating them.

\section{References}

Bidinger, F.R., Blümmel, M., 2007. Determinants of ruminant nutritional quality of pearl millet [Pennisetum glaucum (L.) R. Br.] stover. I. Effects of management alternatives on stover quality and productivity. Field Crops Research 103, 119-128.

Blümmel, M., Rao, P., 2006. Value of sorghum stover, and stover price to quality relationships in stover trading for urban and peri-urban dairy production. International Sorghum and Millets Newsletter 47, 97-100.

Blümmel, M., Paul, C., Goodchild, A.V., Becker, K., 1996. Grinding energy and in vitro gas technique for the assessment of Syrian barley straws: physical and microbial degradation and voluntary feed intake. J. Anim. Physiol. Anim. Nutr. 76, 132-140.

Blümmel, M., Zerbini, E., Reddy, B.V.S., Hash, C.T., Bidinger, F., Ravi, D., 2003. Improving the production and utilization of sorghum and pearl millet as livestock feed: methodological problems and possible solutions. Field Crops Research 84, 123-142.

Govila, O.P., Rai, K.N., Chopra, K.R., Andrews, D.J., Stegmeier, W.D., 1997. Breeding pearl millet hybrids for developing countries: Indian experience. In: Proceedings of the International Conference on Genetic Improvement of Sorghum and Pearl Millet, INTSORMIL, Lincoln, NE, pp. 97-118.

GraphPad Prism, 1994. GraphPad Software, San Diego, CA 9212, USA.

Hash, C.T., Abdu Rahman, M.D., Bhasker Raj, A.G., Zerbini, E., 2000. Molecular markers for improving nutritional quality of crop residues for ruminants. In: Spangenberg, G. (Ed.), Molecular Breeding of Forage Crops. Kluwer Academic Publishers, Dordrecht/Boston/London, pp. 203-219.

Kelley, T.G., Rao, P., 1996. Availability and requirement of different sources of livestock feed in India with special reference to sorghum and millet straw. In: Global Agenda for Livestock Research Proceedings of the Consultation for the South Asia Region, 6-8 June 1995, ICRISAT Asia Center, Patancheru, ILRI, Kenya, pp. 53-65.

Kristjianson, P.M., Zerbini, E., 1999. Genetic enhancement of sorghum and millet residues fed to ruminants. ILRI Impact Assessment Series 3, ILRI Nairobi.
McDonald, P., Edwards, R.A., Greenhalgh, J.F.D., 1988. Animal Nutrition, fourth ed. Longman Scientific \& Technical.

Prasad, K.V.S.V., Ravi, D., Bidinger, F., Hash, C.T., Blümmel, M., 2006. Relations between laboratory traits of 14 pearl millet stover and their digestibility, intake and nitrogen balance in sheep. In: Bakshi, M.P.S., Wadhwa, M. (Eds.), Technological Interventions in Animal Nutrition for Rural Prosperity. Animal Nutrition Society of India \& Indian Council of Agricultural Research, p. 13.

Reddy, B.V.S., Hash, C.T., Stenhouse, J.W., Nigam, S.N., Singh, L., Van Rheenen, H.A., 1995. Crop improvement for livestock feed at ICRISAT ASIA Centre. In: Seetharam, A., Subbarao, A., Schiere, J.B. (Eds.), Crop Improvement and its Impact on the Feeding Value of Straw and Stovers of Grain Cereals in India. Indian Council of Agricultural Research, New Delhi, India and Department of Tropical Animal Production Agricultural University, Wageningen, The Netherland, pp. 85-90.

SAS (Statistical Analysis System), 1988. SAS Institute Inc. Release 6.03 Edition. Cary, New York, USA.

Van Soest, P.J., 1994. Nutritional Ecology of the Ruminant, second ed. Cornell University Press, Ithaca, New York.

Vellaikumar, S., Khan, A., Bidinger, F., Hash, C.T., Blümmel, M., 2006. Variations in fodder value of pearl millet stover when fed to sheep. In: Bakshi, M.P.S., Wadhwa, M. (Eds.), Technological Interventions in Animal Nutrition for Rural Prosperity. Animal Nutrition Society of India \& Indian Council of Agricultrural Research, p. 14.

Vogel, K.P., Sleper, D.A., 1994. Alteration of plants via genetics and plant breeding. In: George, J., Fahey, C. (Eds.), Forage Quality Evaluation, and Utilization. American Society of Agronomy, Madison, WI, pp. 891-921.

Underwood, M.P., Hall, A.J., Zerbini, E., 2000. Genetic enhancement of sorghum and millet residues fed to ruminants: farmers' perception of fodder quality in livelihood systems. Summary Report of PRA Case Studies in Andhra Pradesh, Gujarat, Maharashtra, Karnatka and Rajasthan States. ILRI (International Livestock Research Institute), Nairobi, Kenya and ICRISAT (International Crop Research Institute for the Semi-Arid Tropics), Patancheru, India, $68 \mathrm{pp}$.

Yadav, O.P., Weltzien R.E., 1998. New pearl millet populations for Rajasthan, India. Integrated Systems Project Report Series No. 10. International Crops Research Institute for the Semi-Arid Tropics, Patancheru, India, $88 \mathrm{pp}$. 